\title{
UPACARA POSA DI PURA DALEM DESA PAKRAMAN BANTANG KECAMATAN KINTAMANI, KABUPATEN BANGLI (KAJIAN ŚIWAISTIK)
}

\author{
Anak Agung Ayu Alit Widyawati, Hari Harsananda \\ Universitas Hindu Negeri I Gusti bagus Sugriwa \\ Email: agungwidya67@gmail.com, hariharsananda@gmail.com
}

abstract

Indonesian people when they hear about Hinduism, will be identified with religious rituals or ceremonies. Hindu have Panca Yajña, the five types of yajña, which is an obligation for Hinduism to pay three debts (Tri Rna) and as an effort to maintain harmony in human life and the universe. One of the many religious ceremonies that exist, namely the Posa Ceremony at Pura Dalem which is carried out by the people of Pakraman Bantang Village, Kintamani District, Bangli Regency is a unique ceremony which is a religious tradition applied by the previous ancestors.

The procession of the Posa ceremony is divided into three stages, namely: (1) Planning or preparation for the ceremony; (2) Implementation Stage with various processes; (3) The final stage, by distributing titrha wangsuh pada, surudan or lungsuran, takes place at Bale Agung temple. The Posa ceremony has functions such as: (1) Religious function, as a petition for natural balance; (2) The function of cultural preservation, the Posa ceremony is inherited or passed down from one generation to the next. (3) The social function is to integrate all the people of Pakraman Bantang Village in a spirit of togetherness in the Ngayah. The Siwaistik concept contained in the implementation of the five activities of Śiwa ceremonies, namely: (1) Creation (Srsti), (2) Preserver (Sthiti); (3) Samhara (destroyer); (4) Covering / obscuring (Tirobhawa); and (5) Gift (Anugraha)

Keywords: Posa Ceremony, Pura Dalem, and Śiwaistik

\begin{abstract}
Abstrak
Masyarakat Indonesia apabila mendengar kata Hindu, pasti akan diidentikkan dengan ritual atau upacara-upacara keagamaan. Umat Hindu melaksanakan Panca Yajña yaitu lima macam yajña merupakan suatu kewajiban bagi umat Hindu dalam rangka membayar tiga hutang (Tri Rna) serta sebagai upaya untuk menjaga keharmonisan kehidupan manusia serta alam semesta. Salah satu dari sekian banyak upacara keagamaan yang ada yakni Upacara Posa di Pura Dalem yang dilaksanakan oleh masyarakat Desa Pakraman Bantang, Kecamatan
\end{abstract}


Kintamani, Kabupaten Bangli merupakan suatu Upacara yang unik yang merupakan tradisi keagamaan yang diterapkan oleh para leluhur terdahulu.

Prosesi upacara Posa dibagi menjadi tiga tahap yakni : (1) Tahap Perencanaan atau persiapan upacara; (2) Tahap Pelaksanaan dengan berbagai prosesinya; (3) Tahap Akhir dengan membagikan titrha wangsuh pada, surudan atau lungsuran bertempat di pura Bale Agung. Upacara Posa memiliki fungsi (1) Fungsi Religius yaitu sebagai permohonan keseimbangan alam kehadapan Sang Hyang Widi Wasa; (2) Fungsi Pelestarian Budaya yaitu upacara Posa diwariskan atau dialih turunkan dari satu generasi ke generasi berikutnya (3) Fungsi Sosial yaitu mengintegrasikan seluruh masyarakat Desa Pakraman Bantang dalam suatu semangat kebersamaan ngayah. Adapun Konsep Śiwaistik yang terkandung dalam pelaksanaan upacara Posa lima aktivitas Śiwa yaitu : (1) Penciptaan (Srsti);(2) Pemelihara (Sthiti); (3) Samhara (penghancur); (4) Menutupi/pengaburan (Tirobhawa); dan (5) Karunia (Anugraha)

Kata Kunci: Upacara Posa, Pura Dalem, dan Śiwaistik

\section{PENDAHULUAN}

Masyarakat Indonesia apabila mendengar kata Hindu, pasti akan diidentikkan dengan ritual atau upacara-upacara keagamaan. Upacara dalam agama Hindu termasuk kedalam tiga kerangka dasar agama Hindu, yaitu Tattwa (filsafat), Susila (Etika) dan Upakara (Ritual). Pelaksanaan upacara keagamaan atau yajña pada masyarakat Hindu khususnya di Bali, sering kali terdapat perbedaan tatacara pelaksanaannya antara daerah satu dengan daerah lainnya meskipun maknanya sama. Perbedaan ini umumnya disesuaikan dengan keadaan atau kondisi alam setempat, sehingga sering kali kita mendengar bahwa upacara keagamaan disesuikan dengan desa, kala dan patra, yakni: desa, adalah tempat dari pelaksanaanya upacara atau yajña, kala adalah waktu dilaksanakannya upacara atau yajña tersebut, dan patra adalah bagaimana keadaan dan bentuk pelaksanaan Upacara atau yajña itu.

Umat Hindu melaksanakan Panca Yajña yaitu lima macam yajña yang terdiri dari Dewa yajña, Manusa yajña, Pitra yajña, Rsi yajña dan Bhuta yajña. Kelima macam upacara yajña tersebut merupakan suatu kewajiban bagi umat Hindu dalam rangka membayar tiga hutang (Tri Rna) kepada Tuhan (dewa rna), leluhur (pitra rna) serta kepada guru (Rsi rna), serta sebagai upaya untuk menjaga keharmonisan kehidupan manusia serta alam semesta. Pelaksanaan upacara yajña juga dapat menuntun umat manusia khususnya umat Hindu untuk mencapai kesempumaan kesucian, dan kebahagian lahir maupun batin. serta terbebas dari ikatan-ikatan keduniawian dalam hidup. Salah satu pelaksanaan upacara yajña yang akan dibahas dalam artikel ini adalah pelaksanaan upacara Posa di Pura Dalem yang dilaksanakan oleh masyarakat Desa Pakraman Bantang, Kecamatan Kintamani, Kabupaten Bangli. Upacara Posa adalah suatu korban suci dipersembahkan kehadapan Ida Bhatara Dalem.

Upacara Posa di Pura Dalem yang dilaksanakan oleh masyarakat Desa Pakraman Bantang, Kecamatan Kintamani, Kabupaten Bangli merupakan suatu Upacara yang unik yang 
merupakan tradisi keagamaan yang diterapkan oleh para leluhur terdahulu. Posa juga di sebut Mosa yang dipercaya berasal dari istilah bahasa cina maozen. Maozan berarti dewa tumbuhtumbuhan, atau dewa pemberi hidup bagi mahluk hidup. Dari asal kata maozen berubah pengucapan menjadi Mosa juga disebut Posa. Di Desa Pakraman Bantang, Kecamatan Kintamani, Kabupaten Bangli oleh masyarakat di kenal dengan nama Posa (wawancara, Made Gedong 12 Oktober 2018). Sehingga dalam artikel ini akan difokuskan dalam istilah Posa.

Artikel ini akan membahas bagaimana prosesi dari upacara posa, fungsi, serta makna ajaran yang terkandung dalam pelaksanaan Upacara Posa di Pura Dalem Desa Pakraman Bantang, Kecamatan Kintamani, Kabupaten Bangli karena merupakan suatu upacara yang wajib untuk dilaksanakan.

\section{PEMBAHASAN}

\subsection{Proses Pelaksanaan Upacara Posa}

Menurut Koentjaraningrat (1992: 252), upacara keagamaan terdiri dari empat komponen, antara lain: (1) tempat upacara; (2) momen pada saat upacara; (3) benda-benda dan alat-alat upacara, serta (4) orang-orang yang melakukan upacara. Adapun unsur-unsur tersebut dalam pelaksanaan upacara posa yakni: Upacara posa merupakan suatu upacara yang dilaksanakan di pura dalem desa pakraman bantang, kecamatan kintamani, kabupaten bangli. Upacara ini dilaksanakan pada saat tilem sasih kaulu dengan perhitungan dilaksanakan berdasar dina pawatekan, yaitu pada hari Redite, Anggara, atau Waraspati. Hari tersebut merupakan hari yang sangat baik (dewasa ayu) yang dipercaya oleh masyarakat Desa Pakraman Bantang, Kecamatan Kintamani, Kabupaten Bangli dan telah disepakati oleh Prajuru Desa untuk melaksanakan upacara Posa" (Wawancara, 12 April 2019).

Seperti upacara yajna lainnya, upacara posa juga memerlukan sarana-sarana dalam pelaksanaannya. Sarana ini disebut juga sebagai banten. Banten sesungguhnya berasal dari kata bangten dan terdiri dari dua suku kata bang dan enten. Bang berarti Brahma (Sang Hyang Widhi) sedangkan enten berarti ingat atau dibuat sadar (cetana). Berdasarkan hal tersebut banten berarti mendidik umat Hindu supaya selalu ingat dengan keberadaan Ida Sang Hyang Widhi karena beliaulah yang menciptakan dunia (Sudarsana,1998:19).

Upacara Posa di Desa Pakraman Bantang, Kecamatan Kintamani, Kabupaten Bangli merupakan upacara keagamaan yang pelaksanaannya tidak bisa terlepas dari sarana upacara yang disebut dengan banten. Kitab suci Bhagawad Gita Bab IX sloka 26, ada menguraikan tentang sarana prasarana persembahan, yaitu :

Patram puspam phalam toyam

Yo me bhaktya prayacchati

Tad aham bhaktya-upahrtam

Asnami prayatatmanah

Terjemahannya:

Siapapun yang dengan sujud bhakti kepada-Ku mempersembahkan sehelai daun, sekuntum bunga, sebiji buah-buahan, seteguk air, aku terima sebagai bhakti persembahan dari orang yang berhati suci (Pudja,2004:239). 
Petikan sloka di atas menerangkan bahwa banten terdiri dari unsur bunga, daun, buah, air dan api. Banten yang kecil ataupun besar asalkan dilandasi dengan hati yang suci, tulus iklas maka persembahan tersebut akan diterima oleh Sang Hyang Widhi Wasa. Adapun banten yang digunakan dalam upacara Posa berdasarkan wawancara dengan Jro Jepun adalah sebagai berikut.

1. Bebangkit adalah sebuah banten dengan perlengkapan-perlengkapan upakaranya terdiri dari jerimpen sate, ketupang alit, jerimpen jaja, peras, gelar sanga, jangan sakawali, pakekeh, banten manca, dandanan, tengen-tengenan, sorohan, asagan, suci. Semua Banten tersebut diwadahi sok yang ditujukan kehadapan Ida Sang Hyang Widhi Waça

2. Sorohan itu meliputi : suci, Pejati, sasantun, benang, kelanan, dampulan, rayunan putih kuning dan jajan. Banten Sorohan di haturkan kehadapan Ida Sang Hyang Widhi Waça dengan segala manivestasinya untuk memberkati dunia dan menguasai sumber sandang, pangan dan papan.

3. Phala bungkah, phala wija, dan phala gantung. Perlengkapan upacara tersebut dipasang dan dihaturkan pada tiap-tiap banten yang ada.

4. Sampi Cula, Nasi takilan, Bebangkit, banten apejatian, banten dandanan, jajan, buah, nasi, saur, canang playuan, suci, segehan manca warna,

5. Tuak-arak, air, tirta panglukatan, tirta pamarisuda, tirta anyar, dupa dan api takep.

6. Tabuh rah berupa tajen tlung seet

7. Panglukatan, lis gede, lis duurmangala, pasucian, pabuat, bayuan, tulung urip, payuk anyar, kukusan, bungkak, sibuh pepek, durmangala, basokan, dan perlengkapan lainya (Wawancara, 10 April 2019).

Pelaksanaan upacara Posa dipimpin oleh Paduluan Dulu Apad (jumlahnya delapan belas orang) yang diketuai oleh Jro Bayan. Beliau berwenang nganteb segala jenis bentuk banten yang dipersembahkan oleh masyarakat pada saat pelaksanaan upacara Posa di Pura Dalem Desa Pakraman Bantang, Kecamatan Kintamani, Kabupaten Bangli. Pelaksanaan Upacara Posa menjadi tugas dari Paduluan Dulu Apad yang dipimpin oleh Jro Bayan mulai dari awal hingga akhir sebagai pemuput upacara. Juga bertugas untuk mempersiapkan dan mengerjakan beberapa perlengkapan-perlengkapan upacara. Wewenang tugas Paduluan Dulu Apad yang dipimpin oleh Jro Bayan adalah nganteb atau sebagai pemimpin upacara keagamaan, mengatur adat istiadat dan tradisi (wawancara dengan I Made Gunawan 10 April 2019).

I Gede Sukajaya (Wawancara, 27 April 2019), menyatakan bahwa Secara garis besarnya rangkaian pelaksanaan upacara Posa di Pura Dalem Desa Pakraman Bantang, Kecamatan Kintamani, Kabupaten Bangli dibedakan menjadi tiga tahap yaitu : (1) Tahap Perencanaan, (2) Tahap Pelaksanaan dan (3) Tahap Akhir atau Penutup.

Tahap perencanaan hanya meliputi rapat persiapan pelaksanaan upacara posa, serta menunjuk atau menugaskan warga desa yang memiliki giliran untuk mempersiapkan sarana prasarana dalam pelaksanaan upacara posa. tahap perencanaan dalam upacara Posa dimulai sejak tujuh hari sebelum pelaksanaan upacara Posa, maka Krama Desa Pakraman Bantang, Kecamatan Kintamani, Kabupaten Bangli mengadakan pesangkepan di Balai Agung guna 
membahas hal-hal yang ada hubungannya dengan pelaksanaan upacara tersebut. Pesangkepan tersebut dihadiri oleh seluruh Krama Pengarep, dalam pesangkepan tersebut Paduluan Desa Pakraman Bantang menjelaskan tentang pelaksanaan upacara Posa akan dilaksanakan lagi tujuh hari yang dirangkai dengan Nyepi Desa, masyarakat diharapkan mulai menyiapkan sarana prasarana termasuk sampi yang sudah dicula atau sapi yang berwarna hitam kemerahmerahan dan syarat lainya"

Pelaksanaan upacara posa dimulai dengan Mendak sampi cula yang merupakan sarana utama pada Upacara Posa dan diupacarai di Pura Baleagung. Sampi Cula akan berubah nama menjadi Jro Gede dan masyarakat mekemit siang malam menjaga Jro Gede serta mencarikan makananya. Para daha teruna menjalankan tugasnya mencari ambu dan bambu sebagai sawen dan hiasan pada palinggih-palinggih serta dipasang sehari sebelum pelaksanaan upacara Posa. sawen merupakan sebuah tanda yang dipasang dalam upacara Posa. Tanda tersebut dibuat dari ranting kayu atau dengan menggunakan sebilah bambu yang dihiasi dengan menggunakan janur. Tanda tersebut dipasang dengan cara ditanjapkan ke dalam tanah agar dapat berdiri tegak.

Pagi hari pelaksanaan Upacara Posa para Skaha Ebat menjalankan tugasnya, didahului dengan upacara di Pura Puseh. Dilanjutkan dengan Ngamedalan pajenengan yaitu tombak yang akan dipakai menusuk Jro Gede. Skaha Ebat menancapkan batang kayu di tengah-tengah natah Pura Bale Agung selanjutnya Jro Gede diikat di sana. Jro Bayan dan paduluan dulu apad yang lainya bersiap siap dengan bumbung dari bambu yang dipergunakan untuk tempat darah yang keluar dari Jro Gede nantinya setelah di tusuk dengan pajenengan oleh Jro Bayan. Setelah semua siap pajenengan medal yang dipundut oleh Jro Bayan Mucuk dan Jro Bayan Nyoman. Beliau menari mengelilingi Jro Gede diiringi oleh paduluan lainya. Setelah itu barulah Jro Gede di tusuk dan dibiarkan darahnya mengucur. Sambil berlari memutar mutar karena di ikat pada tiang kayu darah semakin mengucur sampai Jro Gede roboh. Dilanjutkan dengan menyembelihnya dan darahnya di masukan pada bumbung yang telah di siapkan. Acara ini berlangsung sampai tengah hari para Jro Pale Kayu atau istri dari paduluan dulu apad sibuk menata banten yang akan digunakan. Skaha Ebat sibuk menyipakan sarana upakara, demikian juga masyarakat lainya. Para Paduluan dulu apad juga sibuk merangkai segala macam sarana upakara yang diperlukan. Sampai kira-kira jam 13.00 wita semua peralatan diangkut beramai-ramai secara gotong royong menuju Pura Dalem di Pangupetan yang jaraknya kurang lebih $3 \mathrm{Km}$ dengan jalan yang naik turun melewati hutan dan jurang, upacara berlangsung sampai sore. Setelah di tata oleh Jro Palekayu dan para krama desa siap maka para Paduluan Dulu Apad mengambil tempat duduk memulai upacara Posa, dan terakhir dengan muspa. Setelah upacara di pura dalem dianggap selesai, dilanjutkan dengan melaksanakan upacara di Rajepati atau Jaba Tengah Pura Dalem menghadap ke barat. Para Paduluan Dulu Apad mengambil tempat duduk memulai upacara, dirangkaiakan dengan muspa. Acara ini demikian dinanti-nanti oleh seluruh masyarakat karena ada prosesi mencuri daging sapi dan pencuri dikejar dengan menyiramkan tuak arak pada tubuhnya.

Pelaksanaan upacara Posa ditutup dengan membagi tirtha wangsuh pada dan surudan atau lungsuran bertempat di pura Bale Agung. Surudan atau lungsuran tersebut di bagi-bagi bersama seluruh agnggota masyarakat Desa Pakraman Bantang, Kecamatan Kintamani, Kabupaten Bangli. 


\subsection{Fungsi pelaksanaan upacara posa}

\subsubsection{Fungsi Religi}

Religi adalah sistem yang terdiri dari konsep-konsep yang dipercaya dan menjadi keyakinan secara mutlak suatu umat beragama dan upacara-upacara beserta pemuka-pemuka agama yang melaksanakannya. Sistem religi mengatur hubungan antara manusia dengan Tuhan dan dunia gaib, antara sesama manusia dan antara manusia dengan lingkungannya yamg dijiwai oleh suasana yang dirasakan sebagai suasana kekerabatan oleh yang menganutnya (Koentjaraningrat, 1997: 197).

Senada dengan pernyataan tersebut I Wayan Kawi (Wawancara, 27 April 2019).menyatakan bahwa : Upacara Posa memiliki kedudukan yang sangat penting, selain sebagai penghormatan kepada leluhur dan maha pencipta juga untuk memohon kesuburan, kedamaian dan kesejahtraan. Upacara tersebut wajib untuk dilakukan oleh masyarakat Desa Pakraman Bantang setiap tahun. Apabila upacara tersebut tidak dilaksanakan, akan merugikan masyarakat Desa Pakraman Bantang, karena tergolong masyarakat yang agraris yang dimana kehidupan masyarakatnya bergantung dari hasil pertanian. Jika tidak diadakan upacara tersebut akan mempengaruhi keseimbangan kehidupan makrokosmos dan mikrokosmos. Dengan upacara Posa masyarakat Desa Pakraman Bantang dapat bekerja dengan tenang dan dapat menghadapi masa depan dengan penuh kepastian. Kebiasaan ini telah tertanamkan sejak dini, sehingga masyarakatnya terdidik secara spiritual untuk selalu melaksanakan Upacara tersebut.

\subsubsection{Fungsi Pelestarian Budaya}

Pelestarian berasal dari akar kata lestari yang artinya tetap selama-lamanya, kekal, dan tidak berubah sebagai sediakala (Poerwodarminta,1993:592). Pelestaraian adalah suatu usaha yang dilakukan oleh individu, kelompok, atau masyarakat untuk tetap menjaga keutuhan dan keajegan sesuatu hal agar tetap selama-lamanya kekal dan tidak berubah sehingga tetap seperti sediakala.

Budaya berasal dari bahasa sansekerta yaitu buddhayah yakni bentuk jamak dari budhi yang berarti budi atau akal, dengan demikian kebudayaan dapat diartikan hal-hal yang bersangkutan dengan budi dan akal. Kebudayaan adalah keseluruhan gagasan dan karya manusia, yang harus dibiasakannya dengan proses belajar, beserta keseluruhan dari hasil budi dan karyanya (Koentjaraningrat dalam Yudabakti dan Watra,2007:5). Pelestarian budaya merupakan suatu usaha yang dilakukan oleh individu, kelompok, ataupun masyarakat untuk tetap menjaga seluruh gagasan dan karya manusia yang harus dibiasakannya dengan proses belajar, beserta keseluruhan dari hasil budi dan karyanya agar tetap selama-lamanya kekal dan tidak mengalami perubahan, serta tetap seperti sediakala.

Fungsi Pelestarian Budaya pada upacara Posa dapat terlihat pada saat pelaksanaan Upcara Posa yang dilakukan secara bersama-sama oleh anggota masayarakat Desa Pakraman Bantang. Generasi-generasi muda juga ikut terlibat dalam proses pelaksanaan Upacara Posa, sehingga secara tidak langsung ada proses regenerasi yaitu diwariskan atau dialih turunkan dari generasi tua kepada generasi muda. Hal inilah yang mendorong kelestarian dari pada Upacara Posa yang dilaksanakan di Pura Dalem Desa Pakraman Bantang, Kecamatan Kintamani, Kabupaten Bangli. 


\subsubsection{Fungsi Sosial}

Istilah sosial pada ilmu sosial menunjuk pada objeknya yaitu masyarakat, sosial adalah suatu idiologi yang berpokok pada prinsip pemilikan umum atas alat-alat produksi dan jasa-jasa dalam bidang ekonomi (Soekanto dalam Supardan,2008:27). Sosial adalah sesuatu yang menyangkut aspek hidup masyarakat. Berdasarkan pendapat di atas, dapat ditegaskan bahwa sosial adalah segala yang berhubungan dengan sifat-sifat masyarakat (Daryanto,1998:527).

Upacara Posa selain berfungsi sebagai sarana upacara penghormatan terhadap maha Pencipta, juga berfungsi sebagai sarana interaksi serta integrasi sosial dalam usaha memenuhi dan mempertahankan struktur sosial (integrasi masyarakat) yakni kerjasama dari seluruh anggota masyarakat, mulai dari individu, keluarga, lembaga dan masyarakat secara keseluruhan yang menghasilkan persenyawaan berupa adanya konsensus nilai yang samasama dijungjung tinggi. Dalam integrasi sosial terjadi akomodasi, asimilasi dan berkurangnya prasangka-prasangka yang ada dimasyarakat sehingga tidak terjadi konflik, dominasi, tidak banyak sistem yang tidak melengkapi dan timbul integrasi tanpa paksaan. Integrasi sosial yang diharapkan oleh masyarakat Desa Pakraman Bantang diwujudkan dalam bentuk gotong royong. Gotong-royong merupakan sistem budaya yang sangat mendasar atau mendarah daging dalam kehidupan bangsa Indonesia sehingga sulit mengalami perubahahan atau pergeseran dalam waktu yang relatif singkat. Gotong-royong merupakan bentuk kerjasama yang dilandasi oleh solidaritas atau tenggang rasa, rasa cinta, kasih, rasa saling asah-asih-asuh (segalak, sagilik, saguluk, salunglung, sabayantaka), rasa saling memiliki dan lain sebagainya, sehingga terwujudlah kehidupan yang serasi, selaras, harmonis dan keseimbangan. Gotong royong yang dikembangkan di dalam upacara Posa diwujudkan dalam bentuk ngayah (gotong royong yang dilaksankaan di pura).

\subsection{Konsep Śiwaistik yang Terkandung dalam Pelaksanaan Upacara Posa}

Paham Siwaistik merupakan paham yang mendominasi aliran agama Hindu yang berkembang di Indonesia khususnya di Bali, sehingga corak agama Hindu di Bali sangat khas baik secara metafisika maupun secara kebudayaan. Pengaruh ini Nampak kuat, sangat jelas dan tentunya masih dipraktekkan hingga saat ini dikehidupan masyarakat Hindu khususnya di Bali (Suamba, 2009: 271).

Śiwa memiliki lima aktivitas yang disebut dengan Panca Krtya yaitu : Srsti (Pencipta), Sthiti (pemelihara), Samhara (penghancur), Tirobhawa (menutupi/pengaburan), dan Anugraha (karunia). Upacara posa tentunya memiliki kaitan erat dengan panca krtya yaitu:

Pertama Proses Penciptaan; proses ini dilakukan oleh masyarakat dalam rangka mempersiapkan sarana dan prasarana atau bebantenan yang akan digunakan dalam upacara posa. Proses pembuatan banten sama dengan unsur penciptaan karena dihasilkan dari akan pikiran manusia serta diwujudkan dengan keterampilan tangan sesuai dengan keahlian, keterampilan, serta kewenangan masing-masing orang. Prosesnya juga memperhatikan etika agar yang tercipta menjadi persembahan yang suci.

Kedua yaitu pemeliharaan; proses ini ditunjukkan dengan adanya pemeliharaan sapi cula serta sarana prasarana lainnya yang dilakukan oleh masyarakat agar dapat memenuhi kebutuhan sapi cula setiap tahunnya demi terselenggaranya upacara posa. 
Ketiga yaitu aktivitas penghancuran (Samhara); sebagai aktivitas mengembalikan seluruh unsur-unsur kehidupan ke asalnya. Karena pada hakekatnya seluruh cipataan akan kembali pada Sang Hyang Widhi Wasa. Beliau menciptakan Bhuwana Alit dan Bhuwana Agung dari dalam dirinya dan akan kembali pula ke dalam dirinya. Dapat diartikan seperti seekor laba-laba yang membuat jaring-jaring dan pada saatnya jarring-jaringnya tersebut akan kembali ditarik dimasukkan kebadannya. Lontar Buana Kosa menyebutkan sebagai berikut:

Jagat prattistatha, Wisnu palayito bhawet, Rudra sangharake loke, jagat sthawara janggamah. Sang Hyang Brahma sira magawe jagat, Sang Hyang Wisnu sire rumakseng praja, Bhatara Rudra Sira mralayaken rat, ikang rat mwang sthawara janggama, yeka pinralinaken de Sang Hyang Rudra.

(Buana Kosa, VII.27)

Terjemahannya:

Sang Brahma menciptakan dunia, Sang Hyang Wisnu melindungi dunia, Sang Hyang Rudra melebur dunia dengan segala isinya, baik yang tidak bergerak maupun yang bergerak. Itu semua dilebur oleh Sang Hyang Rudra (Ngurah,1994: 90-91)

Berdasarkan kutipan sloka tersebut dapat dinyatakan bahwa seluruh isi dunia ini baik yang bergerak maupun yang tidak bergerak pada suatu saat akan dilebur kembali oleh Śiwa. Peleburan yang dimaksud adalah mengembalikan seluruh unsur-unsur kehidupan pada sumbernya yaitu Bhatara Śiwa. Terkait dengan upacara Posa yang dilaksanakan, proses peleburan dapat dilihat pada proses pemotongan Sampi Cula sebagai persembahan suci. Pemotongan sapi dalam proses upacara Posa bermakna mengambalikan unsur-unsur kehidupan ke asalnya.

Keempat, Aktivitas pengaburan (tirobhawa) terkait dengan penelitian ini dimaksudkan sebagai sebuah proses penetralisir sifat-sifat negatif agar menjadi sifat-sifat positif. Manusia terlahir ke dunia selalu diikat oleh dua hal yang saling berlawan namun selalu berjalan beriringan. Dua hal yang berbeda itu dalam agama Hindu disebut dengan Rwabhineda yaitu baik dan buruk, kebahagiaan dan penderitaan, siang dan malam, positif dan negatif, dan lain sebagainya. Pada upacara posa, cara menetralisir sisi buruk dalam upacara Posa terlihat pada proses pelaksanaan upacara di Rajepati atau Jaba Tengah Pura Dalem menghadap ke Barat. Acara ini demikian dinanti-nanti oleh seluruh masyarakat karena ada prosesi mencuri daging sapi dan pencurinya diteriakin maling serta di kejar dan dilempar memakai tuak dan arak. Pencuri daging sapi merupakan simbolisasi sifat asuri sampat. Sifat-sifat pencuri merupakan sifat para buta, kala, dengen asura, raksasa, jim, tonya, gamang, memedi dan sejenisnya maka perlu diteriaki dan diberikan minuman tuak arak agar sifat tersebut menjadi somya dan menjadi sifat daiwisampat.

Kelima adalah karunia ; Secara umum umat Hindu melaksanakan berbagai bentuk Yajña bertujuan untuk mendapatkan karuania (anugraha) dari Sang Hyang Widhi Wasa. Secara niskala anugrah yang diperoleh melalui upacara Posa adalah kehidupan, keselamatan dan kemakmuran. Masyarakat meyakini anugrah tersebut diberikan oleh Sang Hyang Widhi Wasa melalui perantara tirtha, sehingga aktivitas Anugraha (karunia) dalam upacara Posa terlihat pada tahap awal dan tahap akhir persembahyangan, karena setiap persembahyangan pada umumnya selau diawali dengan menyipratkan tirtha panglukatan dan diakhiri pula dengan 
menyipratkan tirtha Wangsuhpada.Masyarakat petani Desa Pakraman Bantang, pada saat upacara Posa memohon tirtha untuk dicipratkan ke kebun serta dengan persembahan berupa banten dengan tujuan untuk menambah anugrah berupa kesuburan.

Disisi lain aktivitas anugraha pada Upacara Posa, juga dapat dilihat ketika habis persembahyangan yang ditutup dengan membagi surudan atau lungsuran bertempat di Pura Bale Agung. Surudan atau lungsuran tersebut di bagi-bagi bersama seluruh anggota masyarakat Desa Pakraman Bantang.

\section{SIMPULAN}

Berdasarkan analisis di atas maka dapat diambil simpulan sebagai berikut. Prosesi upacara Posa di Pura Dalem Desa Pakraman Bantang, Kecamatan Kintamani, Kabupaten Bangli dibedakan menjadi tiga tahap yaitu : (1) Tahap Perencanaan yaitu mulai dari mengadakan pesangkepan yaitu merencanakan hari pelaksanaan upacara dan persiapan sarana upakara, (2) Tahap Pelaksanaan yaitu dimulai dari mendak Sampi Cula yang akan disembelih, Jro Pale Kayu atau istri dari paduluan dulu apad menata banten yang akan digunakan, Skaha Ebat menyipakan sarana upakara, demikian juga masyarakat lainya. Setelah di tata oleh Jro Palekayu dan para krama desa siap maka para Paduluan Dulu Apad mengambil tempat duduk memulai upacara Posa, dan terakhir dengan muspa (3) Tahap Akhir atau Penutup yaitu ditutup dengan membagikan titrha wangsuh pada serta nunas surudan atau lungsuran bertempat di pura Bale Agung.

Fungsi Upacara Posa Di Pura Dalem Desa Pakraman Bantang, Kecamatan Kintamani, Kabupaten Bangli meliputi (1) Fungsi Religius yaitu sebagai permohonan keseimbangan alam kehadapan Sang Hyang Widi Wasa; (2) Fungsi Pelestarian Budaya yaitu upacara Posa diwariskan atau dialih turunkan dari satu generasi ke generasi berikutnya atau ditransmisikan dari satu generasi ke generasi berikutnya; (3) Fungsi Sosial yaitu mengintegrasikan seluruh masyarakat Desa Pakraman Bantang dalam suatu semangat kebersamaan ngayah.

Konsep Śiwaistik yang terkandung dalam pelaksanaan upacara Posa di Pura Dalem Desa Pakraman Bantang, meliputi lima aktivitas Śiwa yaitu : (1) Penciptaan (Srsti) yaitu proses pembuatan banten; (2) Pemelihara (Sthiti) yaitu pemeliharaan sapi yang akan dijadikan sarana persembahan; (3) Samhara (penghancur) yaitu Proses penyembelihan sapi; (4) Menutupi/pengaburan (Tirobhawa) yaitu masyarakat yang mencuri sampi cula disiram dengan tuak dan arak; dan (5) karunia (Anugraha) yaitu berupa nunas tirtha wangsuh pada dan surudan.

\section{DAFTAR PUSTAKA}

Daryanto. 1998. Kamus Lengkap Bahasa Indonesia. Surabaya: Apollo.

Koentjaraningrat. 1992. Beberapa Pokok Antropologi Sosial. Jakarta : PT Dian Rakyat.

Koentjaraningrat. 1997. Metode-Metode Penelitian Masyarakat. Jakarta: PT Gramedia Pustaka Utama.

Ngurah, I Gusti Rai Mirsha. 1994. Buana Kosa. Denpasar : Upada Sastra.

Poerwadarminta, W.J.S. 1984. Kamus Umum Bahasa Indonesia. Jakarta: Balai Pustaka.

Pudja, I Gede. 2004. Kitab Suci Bhagawad Gita. Surabaya: Paramita. 
Suamba, I. B Putu. 2009. Siwa-Buddha Di Indonesia (Ajaran dan Perkembangannya). Denpasar: Widya Dharma

Sudarsana, IB. 1998. Ajaran Agama Hindu (Filsafat Yadnya). Denpasar: Yayasan Dharma Acarya Percetakan Mantra Sastra.

Supardan, H. Dadang. 2008. Pengantar Ilmu Sosial Sebuah Kajian Pendekatan Struktural. Jakarta: PT Bumi Aksara.

Yudabakti, I Made, Watra, I Wayan. 2007. Filsafat Seni Sakral dalam Kebudayaan Bali. Surabaya: Paramita. 